Bangladesh J. Pl. Breed. Genet., 30(1): 33-37, 2017

\title{
IDENTIFICATION OF SUITABLE VARIETIES FOR SEED PRODUCTION OF JUTE IN NON-TRADITIONAL AREAS OF BANGLADESH
}

\author{
M. Al-Mamun, C. K. Saha, M. G. Mostofa, A. Miah ${ }^{1}$ and M. Z. Hossain ${ }^{1}$ \\ Plant Breeding Division \\ ${ }^{1}$ Genetic Resources and Seed Division \\ Bangladesh Jute Research Institute \\ Manik Mia Avenue, Dhaka 1207
}

\begin{abstract}
The experiment was conducted at Hill Agricultural Research Station, Khagrachari (representing hilly areas), Agricultural Research Station, Satkhira and Jute Research Station, Patuakhali (representing saline areas) with seven varieties of jute and one variety of kenaf to find out the seed production potentiality in non-traditional areas. All varieties were sown in late July to mid August in 2009 to 2011. At hilly station white jute varieties (BJRI Deshi Pat-6, CVL-1 and BJRI Deshi Pat-5) performed better for seed production than tossa jute and kenaf varieties. At saline station (both Satkhira and Patuakhali) kenaf variety HC-95 performed better for seed yield than white and tossa jute varieties (O-9897, OM-1, BJRI Tossa Pat-4 and BJRI Tossa Pat$5)$. The kenaf variety (HC-95) produced the highest yield (0.86 ton/ha) in saline areas. Among the white jute varieties, BJRI Deshi Pat-5 gave the highest yield (0.66 ton/ha) and in case of tossa jute varieties, BJRI Tossa Pat-5 gave the highest seed yield (0.70 ton/ha). Therefore, BJRI Deshi Pat-5 of white jute, BJRI Tossa Pat-5 and HC-95 of kenaf are considered as the best varieties for seed production in hilly and saline areas of Bangladesh, respectively.
\end{abstract}

Keywords: Jute, salinity, hilly areas, bast fibre, seed yield.

\section{INTRODUCTION}

Jute is the second most important bast fibre after cotton, in terms of usage, global consumption, production and availability. It is an important cash crop in Bangladesh and India, which together accounts for about $84 \%$ of world production of jute fibre (Islam, 2009). In Bangladesh around 4 to 5 million small and subsistence farmers derive their livelihood from Jute and Allied Fibre (JAF) crop production while thousands of other workers and employed in its processing, handling, manufacturing (Saha, 2011). Global awareness on 'save the environment" increases the demand of jute. Jute and jute products not only retard ecological degradation but also conserve green environment and atmosphere as a whole. Thus, jute is a crop having a lot of positive benefits in establishment of green economy, soil health and environment. The climate and soil of our country is highly congenial for jute cultivation. Presently, the area under jute and kenaf cultivation is about $8.0-8.2$ lakh hectare with production 85-90 lakh bales. Of the jute cultivated area about $85 \%$ tossa jute, $8 \%$ white jute and $7 \%$ is of kenaf (Saha, 2011). Seed is the basic input for agricultural production. Quality seeds of an improved variety itself provide $20 \%$ additional yield of the crop (Hossain et al., 1994). Bangladesh requires about $5500-6000$ tons jute and kenaf seeds in every year, of which only $10-15 \%$ is produced and distributed by the BADC (Ali et al., 2003). BADC is the only public sector of the country which produces and distributes jute and very few kenaf seeds to the growers. 
On the other hand, jute seed production areas are decreasing at an alarming rate due to unavailability of land. As a result, every year a huge amount of tossa jute and kenaf seeds are introducing through official and unofficial trades from neighboring country. Unofficial imports of jute and kenaf seed have no guarantee of its quality and are one of the major causes of low yield (Islam, 2009). Due to supply of insufficient quantity seed from the public sector and due to high demand of jute seed, sometimes unauthorized traders are taking the opportunity of introducing poor quality seeds in the market. So it is necessary to check unauthorized traders by increasing jute and kenaf seed production in the country. Under the present Jute production acreage, Bangladesh requires about 5000 to 6000 metric tons of jute and kenaf seed per year. Out of this requirement, BADC supplied only 12-15\% of the total jute and allied fibers seed (Al-Mamun and Saha, 2017). Rest of seed farmers collect from their friends or neighbors. Sometimes, the introduced seeds (not all) have failed to attain the desired standard.

To execute, there is a big zone in the non-traditional areas like hilly and coastal (saline) areas of Bangladesh where jute seed could be grown and may be an alternate to meet the huge demand of different varieties of jute and kenaf seed. In Bangladesh, more than $30 \%$ of the net cultivable area is the coastal belts. About 0.83 million hectares land is affected by varying degrees of soil salinity (Karim et al., 1990). Salinity causes unfavorable environmental and hydrological situation restricting the normal crop production throughout the year (Khan et al., 2008). The major challenge for increased production is the shortage of land for jute and kenaf seed cultivation. The increased demand for food and other crops has pushed jute and kenaf into the marginal lands. On the other hand, jute and kenaf seeds are grown in the kharif- 2 and rabi season and therefore, there is no chance of shifting aman rice and many high value rabi crops for jute and kenaf seed cultivation. In this situation, jute and kenaf seed production can be the right choice as it has tolerance capacity and can give minimum yield under stress environment. There was no organizational source of kenaf seeds and about $80 \%$ of the requirement of tossa jute seeds are importing from India. Though major portion of seeds are handling by the private sectors but none of their seed is producing in the country. Due to this seed shortage, farmers of Bangladesh especially in the border areas use low quality seed which reaches to them through illegal ways. With this view kept in mind the experiment was undertaken to identify varieties suitable for jute/kenaf seed production in non-traditional areas of Bangladesh.

\section{MATERIALS AND METHODS}

The conventional method of jute seed production is not enough at all to meet the demand of the farmers. As jute is a short day crop, it remains in vegetative phase upto October, the seed crop faces many natural hazards in long staying in the field and produces poor quality seeds (Hossain et al., 1994). This problem, however, solved by adopting the late sown technology of jute seed production (Ali et al., 2005), which to be sown in the month of July and August and harvested in December and January (Hossain et al., 1994). Jute seed produced in late sown condition showed unique both in quantity and qualitative attributes (Hossain et al., 1994). To find out the suitable varieties, areas and merits of seed yield of late jute seed production technology the experiment was conducted at Hilly Agricultural Research Station, BARI, Khagrachari, Agricultural Research Station, BARI, Benerpota, Satkhira and Jute Research Sub-station, Kalapara, Patuakhali with eight varieties of jute and kenaf. Seeds of three white jute varieties viz. CVL-1, BJRI Deshi Pat-5 and BJRI Deshi Pat-6, four tossa jute varieties viz. O-9897, OM-1, BJRI Tossa Pat -4 and BJRI Tossa Pat-5 and one kenaf variety HC-95 were sown in late July to Mid 
August through direct seeding following RCBD design with three replications. Unit plot size was $4.0 \mathrm{~m} \times 3.0 \mathrm{~m}=12.0 \mathrm{sq}$. $\mathrm{m}$. Space between plots and between replications was $60 \mathrm{~cm}$ and $1.0 \mathrm{~m}$, respectively. Other cultural practices were followed as per BJRI recommendation. Plants were harvested November to January when $60-70 \%$ capsules become brown in color. Location specific three years average data of seed yield and yield attributing characters were analyzed with the help of computer statistical package (MSTAT). The mean differences among the treatments were adjusted as per Least Significant Difference (LSD) and T-test at 0.05 level (Gomez and Gomez, 1984).

\section{RESULTS AND DISCUSSION}

Analysis of variance revealed that non significant variances were observed among the treatments for plant population, plant height, branches plant ${ }^{-1}$, pods plant ${ }^{-1}$, seeds pod $^{-1}$, 1000-seed weight and seed yield at hilly and saline areas (Table 1,2). Among white jute varieties, the highest plant population was observed in BJRI Deshi Pat-6 at Khagrachari, CVL-1 at Satkhira and BJRI Deshi Pat-5 at Patuakhali station. On the other hand, BJRI Tossa Pat-5 showed the highest plant population at Khagrachari and Satkhira station and OM-1 at Patuakhali station among tossa jute varieties. Seed yield of jute in saline areas (Satkhira and Patuakhali) was lower than hilly area (Khagrachari). At Satkhira and Patuakhali, kenaf variety (HC-95) performed better for seed yield than white and tossa jute varieties. It is because kenaf is more tolerant to salinity than white and tossa jute.

Table 1. Performance of eight varieties of jute and Kenaf seed yield and yield related traits in hilly area (Khagrachari)

\begin{tabular}{|c|c|c|c|c|c|c|c|}
\hline Varieties & $\begin{array}{c}\text { PN } \\
\left(\text { lacha }^{-1}\right)\end{array}$ & $\begin{array}{l}\mathrm{PH} \\
(\mathrm{m})\end{array}$ & $\mathrm{BP}$ & PP & SP & TS $(\mathrm{g})$ & $\begin{array}{c}\text { SY } \\
\left(\text { tha }^{-1}\right)\end{array}$ \\
\hline \multicolumn{8}{|c|}{ White Jute } \\
\hline CVL-1 & 3.73 & 1.96 & 3.67 & 31.00 & 33.00 & 3.53 & 0.82 \\
\hline BJRI Deshi Pat-5 & 3.46 & 2.03 & 5.33 & 30.67 & 35.33 & 4.00 & 0.77 \\
\hline BJRI Deshi Pat-6 & 4.50 & 1.77 & 4.33 & 36.33 & 36.00 & 3.60 & 0.92 \\
\hline Mean & 3.90 & 1.92 & 4.44 & 32.67 & 34.78 & 3.71 & 0.84 \\
\hline $\operatorname{LSD}_{(0.05)}$ & NS & NS & NS & NS & NS & NS & NS \\
\hline \multicolumn{8}{|c|}{ Tossa Jute } \\
\hline O-9897 & 3.36 & 1.96 & 3.00 & 33.33 & 167.67 & 2.40 & 0.57 \\
\hline OM-1 & 3.13 & 2.07 & 3.33 & 16.00 & 149.00 & 2.20 & 0.75 \\
\hline BJRI Tossa Pat-4 & 3.37 & 1.99 & 3.33 & 32.00 & 170.33 & 2.40 & 0.62 \\
\hline BJRI Tossa Pat-5 & 3.42 & 1.87 & 3.33 & 29.33 & 172.33 & 2.10 & 0.61 \\
\hline Mean & 3.32 & 1.97 & 3.25 & 27.67 & 164.83 & 2.28 & 0.64 \\
\hline $\operatorname{LSD}_{(0.05)}$ & NS & NS & $\mathrm{NS}$ & NS & NS & NS & NS \\
\hline \multicolumn{8}{|c|}{ Kenaf } \\
\hline HC-95 & 2.26 & 2.13 & 0.00 & 22.00 & 17.67 & 28.30 & 0.48 \\
\hline
\end{tabular}

$\mathrm{PN}=$ plant population, $\mathrm{PH}=$ plant height, $\mathrm{BP}=$ branches plant $^{-1}, \mathrm{PP}=$ pods plant $^{-1}, \mathrm{SP}=$ seeds pod $^{-1}, \mathrm{TS}=1000$-seed weight $(\mathrm{g}), \mathrm{SY}=$ seed yield $(\mathrm{t} / \mathrm{ha})$

Comparatively higher seed yield was obtained at Satkhira followed by Khagrachari station. At hilly station (Khagrachari), deshi jute varieties (BJRI Deshi Pat-6, CVL-1 and BJRI Deshi Pat-5) performed better for seed production than tossa jute and kenaf varieties. Pooled mean (Table 5) showed that seed yield was the highest $(0.867$ ton/ha) in kenaf variety HC-95. 
Table 4. Performance of eight varieties of jute and Kenaf seed yield and yield related traits in saline area

\begin{tabular}{|c|c|c|c|c|c|c|c|c|}
\hline $\begin{array}{c}\text { Locations \& } \\
\text { Soil Salinity } \\
\text { (EC) levels }\end{array}$ & Varieties & $\begin{array}{c}\text { PN } \\
\left(\text { lacha }^{-1}\right)\end{array}$ & $\begin{array}{l}\mathrm{PH} \\
(\mathrm{m})\end{array}$ & $\mathrm{BP}$ & PP & SP & $\begin{array}{l}\text { TS } \\
(\mathrm{g})\end{array}$ & $\begin{array}{c}\text { SY } \\
\left(\text { tha }^{-1}\right)\end{array}$ \\
\hline \multirow{15}{*}{ 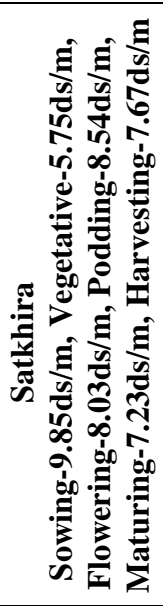 } & \multicolumn{8}{|c|}{ White Jute } \\
\hline & CVL-1 & 2.12 & 0.85 & 2.00 & 30.33 & 30.33 & 3.40 & 0.63 \\
\hline & BJRI Deshi Pat-5 & 1.51 & 0.98 & 2.00 & 54.00 & 31.67 & 3.94 & 0.77 \\
\hline & BJRI Deshi Pat-6 & 1.64 & 1.07 & 3.67 & 37.67 & 34.67 & 3.91 & 0.61 \\
\hline & Mean & 1.76 & 0.97 & 2.56 & 40.67 & 32.22 & 3.75 & 0.67 \\
\hline & $\operatorname{LSD}_{(0.05)}$ & NS & NS & NS & NS & NS & NS & NS \\
\hline & \multicolumn{8}{|c|}{ Tossa Jute } \\
\hline & O-9897 & 1.28 & 0.85 & 8.33 & 49.00 & 110.00 & 2.20 & 0.79 \\
\hline & OM-1 & 1.12 & 1.10 & 10.00 & 56.67 & 140.67 & 2.02 & 0.74 \\
\hline & BJRI Tossa Pat-4 & 1.25 & 0.93 & 3.00 & 51.67 & 117.00 & 2.01 & 0.49 \\
\hline & BJRI Tossa Pat-5 & 1.35 & 0.99 & 8.00 & 36.67 & 147.00 & 2.01 & 0.80 \\
\hline & Mean & 1.25 & 0.97 & 7.33 & 48.50 & 128.67 & 2.06 & 0.71 \\
\hline & $\operatorname{LSD}_{(0.05)}$ & NS & NS & NS & NS & NS & NS & NS \\
\hline & \multicolumn{8}{|c|}{ Kenaf } \\
\hline & HC-95 & 1.50 & 0.99 & 2.67 & 23.67 & 17.00 & 26.48 & 0.85 \\
\hline \multirow{15}{*}{ 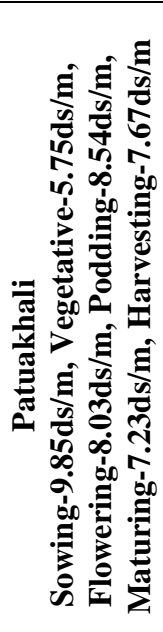 } & \multicolumn{8}{|c|}{ White Jute } \\
\hline & CVL-1 & 4.37 & 1.06 & 8.33 & 44.33 & 35.33 & 4.23 & 0.45 \\
\hline & BJRI Deshi Pat-5 & 4.62 & 1.20 & 11.67 & 55.00 & 39.67 & 3.84 & 0.44 \\
\hline & BJRI Deshi Pat-6 & 3.53 & 1.07 & 11.33 & 47.33 & 37.33 & 4.01 & 0.43 \\
\hline & Mean & 4.17 & 1.11 & 10.44 & 48.89 & 37.44 & 4.03 & 0.44 \\
\hline & $\operatorname{LSD}_{(0.05)}$ & NS & NS & NS & NS & NS & NS & NS \\
\hline & \multicolumn{8}{|c|}{ Tossa Jute } \\
\hline & O-9897 & 4.14 & 1.32 & 2.67 & 17.33 & 169.33 & 3.13 & 0.46 \\
\hline & OM-1 & 4.40 & 1.42 & 3.67 & 19.67 & 158.00 & 3.00 & 0.55 \\
\hline & BJRI Tossa Pat-4 & 3.68 & 1.28 & 3.33 & 20.33 & 165.00 & 2.97 & 0.55 \\
\hline & BJRI Tossa Pat-5 & 3.46 & 1.25 & 3.00 & 17.33 & 183.00 & 2.97 & 0.68 \\
\hline & Mean & 3.92 & 1.32 & 3.17 & 18.67 & 168.83 & 3.02 & 0.56 \\
\hline & $\operatorname{LSD}_{(0.05)}$ & NS & NS & NS & NS & NS & NS & NS \\
\hline & \multicolumn{8}{|c|}{ Kenaf } \\
\hline & HC-95 & 3.49 & 1.21 & 0.00 & 14.67 & 18.67 & 29.70 & 1.27 \\
\hline
\end{tabular}

Table 5. Pooled mean of eight varieties of Jute and Kenaf for seed yield and related traits in one hilly and two saline areas

\begin{tabular}{c|c|c|c|c|c|c|c|c}
\hline & Varieties & $\begin{array}{c}\text { PN } \\
\left(\text { lacha }^{-1}\right)\end{array}$ & $\begin{array}{c}\text { PH } \\
(\mathrm{m})\end{array}$ & BP & PP & SP & TS (g) & $\begin{array}{c}\text { SY } \\
\left(\text { tha }^{-1}\right)\end{array}$ \\
\hline White Jute & CVL-1 & 3.40 & 1.29 & 4.67 & 35.22 & 32.89 & 3.72 & 0.63 \\
& BJRI Deshi Pat-5 & 3.20 & 1.37 & 6.33 & 46.56 & 35.56 & 3.93 & 0.66 \\
& BJRI Deshi Pat-6 & 3.22 & 1.30 & 6.44 & 40.44 & 36.00 & 3.84 & 0.65 \\
\hline Tossa Jute & O-9897 & 2.93 & 1.38 & 4.67 & 33.22 & 149.00 & 2.52 & 0.60 \\
& OM-1 & 2.88 & 1.53 & 5.67 & 33.22 & 149.22 & 2.41 & 0.68 \\
& BJRI Tossa Pat-4 & 2.77 & 1.40 & 3.22 & 34.67 & 150.78 & 2.46 & 0.56 \\
& BJRI Tossa Pat-5 & 2.75 & 1.37 & 4.78 & 27.78 & 167.56 & 2.36 & 0.70 \\
\hline Kenaf & HC-95 & 2.42 & 1.44 & 0.89 & 20.11 & 17.78 & 28.16 & 0.86 \\
\hline
\end{tabular}

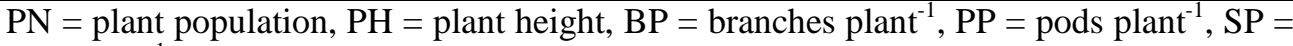
seeds pod $^{-1}, \mathrm{TS}=1000$-seed weight, $\mathrm{SY}=$ seed yield $(\mathrm{t} / \mathrm{ha})$ 
Among deshi jute varieties, BJRI Deshi Pat-5 gave the highest seed yield ( 0.658 ton/ha) and in case of tossa jute varieties, BJRI Tossa Pat- 5 gave the highest seed yield $(0.696$ ton/ha). The agriculture climate of Bangladesh is very much suitable for quality fibre production. Supply of quality jute and kenaf seed will ensure the fibre quality to a great extent. The activities of private sectors regarding jute and kenaf seed are limited on seed import only. So it is time to bring the private sector to produce jute seed domestically. Considering seed yield performance it may be concluded that BJRI Deshi Pat-5 of deshi jute and BJRI Tossa Pat-5 of tossa jute may be considered as the best varieties for seed production in non-traditional areas (hilly and saline). On the other hand, Kenaf variety HC-95 is also suitable for seed production in saline zone may be an alternate source.

\section{REFERENCES}

Alam, M. M. 2017. Pater Otit, Bartaman and Bobisot, National Jute Dibos-2017, Dhaka, Bangladesh. 6 March, Organized by Ministry of Textiles and Jute, Bangladesh. P. $15-19$.

Ali, M. Abbas and M. Al-Mamun. 2013. Jute seed production and storage. The Reflector. (1-15 April 2013), 2(5): 23-25.

Ali, S. M., M. M. Haque, A. B. Siddique, A. F. Mollah and M. N. Islam. 2003. Phenology growth and seed yield of tossa jute (Corchorus olitorius L.) in late sown technology. Bangladesh Journal of Agriculture. 27 \& 28: 91-97.

Ali, S. M., M. M. Haque, A. B. Siddique, A. F. Mollah and M. N. Islam. 2005. Effect of sowing date on the phenology growth and seed yield of tossa jute (Corchorus olitorius L.) in late sown technology. Bangladesh Journal of Agriculture. 27 \& 28: 91-97.

Al-Mamun, M. and C. K. Saha. 2017. BJRI udbavito Pat, Kenaf o Mesta Phosoler Procholito Jaat. First Edn. Bangladesh Jute Research Institute. Dhaka. p. 30.

Gomez, A. K. and A. A. Gomez. 1984. Statistical Procedure for Agric. Res. Second Edn. Intnl. Rice Res. Inst. Manila, Philippines. pp. 139-207.

Hossain, M. A., S. A. Mannan, M. K. Sultana and A. L. Khandakar. 1994. Survey on the constraints of quality jute seed at farm level. Ministry of Agriculture, Agricultural Support Service Project. GOB/World Bank/ODA seed technological research team, Bangladesh Jute Research Institute. Dhaka. P. 25.

Islam, M. M. 2009. Jute Seed Technology. 397, Middle Monipur, Mirpur, Dhaka. p. 01.

Karim, Z., S. G. Hussain and M. Ahmed. 1990. Salinity problems and crop intensification in the coastal regions of Bangladesh. Soil Publication 33. BARC. p. 63.

Khan, M. S., M. M. Rahman, R. A. Begum, M. K. Alam, A. T. M. A. I. Mondol, M. S. Islam and N. Salahin. 2008. Research experiment with problem soils of Bangladesh. Soil Science Publication (8), Soil Science Division, Bangladesh Agricultural Research Institute. p.1-25.

Saha, C. K. 2011. Jute Seed Management in Bangladesh. Procedings, International Seminar on Strengthening of Collaboration for Jute, Kenaf and Allied Fibres Research and Development, 8-9 June, 2011. International Jute Study Group (IJSG), Dhaka, Bangladesh. 